\title{
Rock Landslides Induced by Earthquakes: A Study on Influence of Strength Criterion on Limit Equilibrium Stability Analysis
}

\author{
S. Amir Reza Beyabanaki
}

McMillen Jacobs Associates, Walnut Creek, CA, USA

\begin{abstract}
The stability analysis of landslides is important because they are major geological hazards in many parts of the world. In this paper, the most common and traditional methods for the analysis of slope stability - i.e., Limit Equilibrium Methods — are used to investigate the influence of using different strength criteria on stability analysis of rock landslides subjected to a seismic load. For this purpose, four different Limit Equilibrium Methods including (1) Bishop, (2) Janbu, (3) Spencer, and (4) MorgensternPrice are used by incorporating Mohr-Coulomb and Generalized Hoek-Brown strength criteria to model slopes with different properties and rock types - (1) Siltstone, (2) Limestone, (3) Sandstone, and (4) Granite. This study shows that when Generalized Hoek-Brown criterion is used for slope stability analysis, the relative difference of both the predicted minimum factors of safety and areas of potential failure surface - with respect to the cases with Mohr-Coulomb criterion - increases as the strength of rock mass increases. Also, when Generalized Hoek-Brown criterion is used, lower values for both the minimum factor of safety and area of potential failure surface - compared to the cases with Mohr-Coulomb criterion - are predicted for weak rock masses. However, for rock masses with high strength, higher values for both the minimum factor of safety and area of potential failure surface are obtained when Generalized Hoek-Brown criterion is used. The findings of this study can help geotechnical, civil, and mining engineers select the appropriate rock strength criterion for slope stability analysis and design of slope stabilization measures, and to predict landslides.
\end{abstract}

Key Words: Rock Landslide, Slope stability Analysis, Earthquake, Limit Equilibrium Methods, Mohr-Coulomb.

\section{INTRODUCTION}

Rock landslides not only can cause huge economic losses but also can seriously threaten the safety of people's lives and properties [1-4], therefore it is important to predict them accurately by calculating the safety factor of the slopes. The methods used to analyze slope stability are (1) Limit Equilibrium Method [5-7], (2) Limit Analysis Method [8-10], and (3) Numerical Modeling Method [11-12]. Numerical methods used to analyze slopes are usually the Finite Difference Method (FDM) [13, 14], Finite Element Method (FEM) [15], Discontinuous Deformation Analysis (DDA) [16, 17], and Discrete Element Method (DEM) [18]. Analysis of rock slopes requires evaluation of factor of safety for the sliding mass and among these calculation methods, Limit Equilibrium Method is the most famous one for determination of factor of safety of any slopes against failure [19, 20]. The most important Limit Equilibrium Methods are Bishop, Janbu, Spencer, and Morgenstern-Price [21].

Mohr-Coulomb and Hoek-Brown strength criteria are the most popular strength criteria used for expressing rock mass behavior [19]. There is no research published on investigating the influence of strength criterion on stability analysis of rock slopes under seismic conditions using different methods of Limit Equilibrium although there are many studies on incorporating rock strength criteria and using them for slope stability analysis. For instance, Sarkar et al. [22] studied the stability of two excavated slopes in the Pakyong region of Sikkim Himalayas in India. They estimated the shear strength parameters using Generalized Hoek-Brown criterion. Deng et al. [23] proposed a new method for rock slope stability analysis that combines the Limit Equilibrium Method with a simplified form of the Hoek-Brown strength criterion derived using a Taylor series expansion. Kumar et al. [24] performed rock slope analyses using Nonlinear Hoek-Brown criterion with Equivalent Mohr-Coulomb strength parameters. For this purpose, they used Limit equilibrium technique-based Morgenstern-Price and Spencer's method to calculate factors of safety of the slopes. Kang et al. [25] used the Generalized Hoek-Brown criterion to assess rock slope stability of open pit mine Chaarat in Kyrgyz Republic. Michalowski and Park [26] analyzed a slope instability in a geomaterial governed by the Hoek-Brown criterion. Wei et al. [27] used Limit Equilibrium Method and proposed new and rapid stability charts for analyzing the stability of rock slopes based on Generalized Hoek-Brown criterion. Kang et al. [28] used Limit Equilibrium Method based on Generalized Hoek-Brown criterion to perform a probabilistic slope stability assessment under seismic conditions. Finally, Kumar et al. [29] developed stability charts of rock slopes using Limit Equilibrium Method and incorporating Generalized Hoek-Brown criterion to determine factors of safety of a rock slope against failure considering different horizontal seismic coefficients. 
In this paper, four different Limit Equilibrium Methods-Bishop, Janbu, Spencer, and Morgenstern-Price-are used by incorporating Mohr-Coulomb and Generalized Hoek-Brown criteria to study the impact of strength criterion on limit equilibrium stability analysis. For this purpose, four different properties and rock types including Siltstone, Limestone, Sandstone, and Granite are considered to obtain a better understanding of the influence of strength criterion on limit equilibrium stability analysis.

\section{ROCK STRENGTH CRITERIA FOR LIMIT EQUILIBRIUM SLOPE STABILITY ANALYSIS}

Failure surfaces in Limit Equilibrium Method are divided into several slices based on force and/or moment equilibrium [30]. There are several methods that assume different interslice and equilibrium conditions to calculate force and/or moment equilibrium for the slices and the most important ones are Bishop, Janbu, Spencer, and Morgenstern-Price [21]. In this section, the most important rock strength criteria used for Limit Equilibrium slope stability analysis are presented.

\subsection{Mohr-Coulomb Criterion}

Mohr-Coulomb shear criterion has been widely used for slope stability analysis using Limit Equilibrium Method for both soil and rock slopes. In this criterion, it is assumed that failure is controlled by the maximum shear stress. The failure shear stress depends on the normal stress in Mohr-Coulomb criterion and can be written as [31]:

$$
\tau=c-\sigma \tan \varphi
$$

Where $\tau=$ shear stress; $\sigma=$ normal stress; $c=$ cohesion; and $\varphi=$ friction angle.

\subsection{Generalized Hoek-Brown Criterion}

An empirical Hoek-Brown strength criterion for estimating shear strength parameter for hard rock mass from experimental studies performed on rock [32]. Later, nonlinear Hoek-Brown strength criterion for all classes of rock mass was developed [19]. The nonlinear Generalized Hoek-Brown criterion is well-known among the researcher for determining the strength of rock mass [24].

The Generalized Hoek-Brown criterion is expressed as follows [19]:

where,

$$
\begin{gathered}
\tau=\left(\sigma_{n}-\sigma_{3}\right) \sqrt{1+a m_{b}\left(\frac{m_{b}}{\sigma_{c i}} \sigma_{3}+s\right)^{a-1}} \\
\sigma_{n}=\sigma_{3}+\frac{\sigma_{c i}\left(\frac{m_{b}}{\sigma_{c i}} \sigma_{3}+s\right)^{a}}{2+a m_{b}\left(\frac{m_{b}}{\sigma_{c i}} \sigma_{3}+s\right)^{a-1}}
\end{gathered}
$$

$$
\begin{gathered}
m_{b}=m_{i} \exp \left(\frac{G S I-100}{28-14 D}\right) \\
s=\exp \left(\frac{G S I-100}{9-3 D}\right) \\
a=0.5+\frac{e^{\left(\frac{-G S I}{15}\right)}-e^{\left(\frac{-20}{3}\right)}}{6}
\end{gathered}
$$

and $\sigma_{1}=$ major effective principal stress at failure; $\sigma_{3}=$ minor effective principal stress at failure; $\sigma_{c i}=$ uniaxial compressive strength of the intact rock material; GSI = Geological Strength Index (A GSI value of 0 represents a rock mass of very poor quality and a value equal to 100 signifies intact rock with very good strength); $\mathrm{D}=$ disturbance factor to express the presence of initial disturbance in the rock mass caused by stress relaxation and damage.

\section{METHODOLOGY AND MODELING}

The geometry shown in Figure 1 is considered to perform an investigation on the influence of rock strength criterion on the slope stability analysis using Limit Equilibrium Method. As can be seen, the slope height and inclination angle are $10 \mathrm{~m}$ and $73^{\circ}$, respectively.

Four different cases including different properties and rock types — Siltstone, Limestone, Sandstone and Granite — with two different rock shear criteria - Mohr-Coulomb and generalized Hoek-Brown - are considered for this study. RocData software Version 5.0 [33] is used to obtain the rock mass properties for both criteria. The properties and rock types for each case are presented in Figure 2. It should be noted that the rock mass properties range from the weakest (i.e., Siltstone) to the strongest (i.e., Granite). The slope stability analysis for all the methods (Bishop, Janbu, Spencer and Morgenstern-Price) is carried out using SLIDE software version 9.008 [34]. A horizontal seismic load coefficient of 0.25 is considered for all cases. 


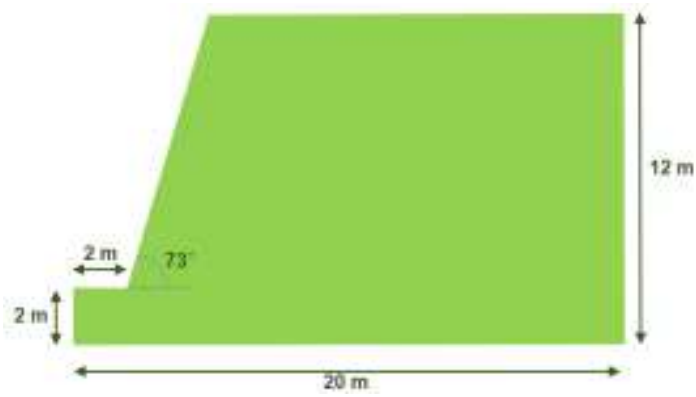

Figure 1: Geometry of slope used for this study

\begin{tabular}{|c|c|c|c|}
\hline Siltstone & Limestone & Sandstone & Granite \\
\hline Hoek Brown Classification & Hoek Brown Classification & Hoek Brown Classification & Hoek Brown Classification \\
\hline $\begin{array}{l}\text { intact uniaxial } 35 \mathrm{MPa} \\
\text { compressive } \\
\text { strength }\end{array}$ & $\begin{array}{l}\text { intact uniaxial } 75 \mathrm{MPa} \\
\text { compressive } \\
\text { strength. }\end{array}$ & $\begin{array}{l}\text { intact uniaxial } 100 \mathrm{MPa} \\
\text { compressive } \\
\text { strength }\end{array}$ & $\begin{array}{l}\text { intact uniaxial } 250 \mathrm{MPa} \\
\text { compressive } \\
\text { strength }\end{array}$ \\
\hline GSI 10 & GSI 40 & $\operatorname{GSI} 150$ & GSIB1 \\
\hline mi & mi 12 & mi17? & mi 32 \\
\hline intact modulus $13125 \mathrm{MPa}$ & intact modulus $37500 \mathrm{MPa}$ & intact modulus $27500 \mathrm{MPa}$ & intact modulus $105250 \mathrm{MPa}$ \\
\hline modulus ratio 375 & modulus ratio 500 & modulus ratio 275 & modulus ratio $\$ 25$ \\
\hline Hoek Brown Criterion & Hoek Brown Criterion & Hoek Brown Criterion & Hoek Brown Criterion \\
\hline $\mathrm{mb} 0.281$ & $\mathrm{mb} 1.408$ & $\mathrm{mb} 2.851$ & mb16.235 \\
\hline s4.54e-005 & 50.001 & 50.004 & $\$ 0.121$ \\
\hline unit weight $0.023 \mathrm{M} / \mathrm{N} / \mathrm{m} 3$ & unit weight $0.025 \mathrm{~m} / \mathrm{N} / \mathrm{m} 3$ & unit weight $0.026 \mathrm{MN} / \mathrm{m} 3$ & unit weight $0.027 \mathrm{MN} / \mathrm{m} 3$ \\
\hline slope height $10 \mathrm{~m}$ & slope height $10 \mathrm{~m}$ & slope height $10 \mathrm{~m}$ & slope height $10 \mathrm{~m}$ \\
\hline Mohr Coulomb Fit & Mohr Coulomb Fit & Mohr Coulomb Fit & Mohr Coulomb Fit \\
\hline cohesion $0.044 \mathrm{MPa}$ & cohesion $0.306 \mathrm{MPa}$ & cohesion $0.6 \mathrm{MPa}$ & cohesion 7.501 MPa \\
\hline friction angle $39.212 \mathrm{deg}$ & friction angle 60.874 deg & friction angle 65.682 deg & friction angle $70.887 \mathrm{deg}$ \\
\hline
\end{tabular}

Figure 2: Rock Data results for rock mass properties

\section{RESULTS}

For this study, a total of 32 cases ( 8 models for each rock type) were modeled. The results obtained from modeling for each rock type are presented below.

\subsection{Case 1: Siltstone}

The model configuration, potential failure surfaces, and calculated minimum factor of safety obtained from the modeling for Mohr-Coulomb and Generalized Hoek-Brown criteria for case 1 (i.e., rock type of Siltstone) are presented in Figures 3 and 4, respectively. The minimum factors of safety for case 1 calculated using Bishop, Janbu, Spencer, and Morgenstern-Price methods with Mohr-Coulomb criterion are 1.265, 1.260, 1.278 and 1.290, respectively. Also, the areas of potential failure surface predicted by using Bishop, Janbu, Spencer, and Morgenstern-Price methods are $33.30 \mathrm{~m}^{2}, 36.50 \mathrm{~m}^{2}, 26.41 \mathrm{~m}^{2}$, and $28.60 \mathrm{~m}^{2}$, respectively. As can be seen, for this case, Janbu and Morgenstern-Price methods predict the minimum and maximum values of the minimum factor of safety, respectively, and Spencer and Janbu predict the minimum and the maximum values of the area of potential failure surface, respectively, when Mohr-Coulomb criterion is used for slope stability analysis.

For the case with Generalized Hoek-Brown criterion, using Bishop, Janbu, Spencer and Morgenstern-Price methods, the calculated minimum factors of safety are $0.969,0.846,0.915$ and 0.917 , respectively, and the predicted areas of potential failure surface are $17.74 \mathrm{~m}^{2}, 16.18 \mathrm{~m}^{2}, 17.46 \mathrm{~m}^{2}, 15.27 \mathrm{~m}^{2}$, respectively. Therefore, the minimum and maximum values of the minimum factors of safety are obtained by using Janbu and Bishop methods, respectively. Furthermore, Morgenstern-Price and Bishop methods predict the minimum and maximum values of the area of potential failure surface, respectively. The results obtained by using Generalized Hoek-Brown criterion show that the slope is not stable, and a landslide is expected to occur because all the calculated minimum factors of safety are less than 1.0 in this case.

\subsection{Case 2: Limestone}

Figures 5 and 6 show the model configuration, potential failure surfaces, and minimum factors of safety obtained from the analysis using Bishop, Janbu, Spencer, and Morgenstern-Price methods for Mohr-Coulomb and Generalized Hoek-Brown criteria, respectively, for the rock type of Limestone. The minimum factors of safety for this case using Mohr-Coulomb criterion are 5.680, 5.836, 5.600 and 5.629 calculated using Bishop, Janbu, Spencer and Morgenstern-Price methods, respectively. 


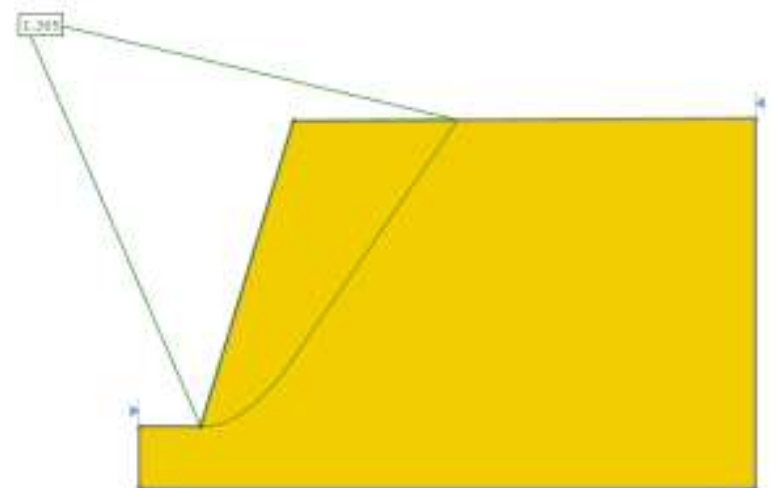

(a)

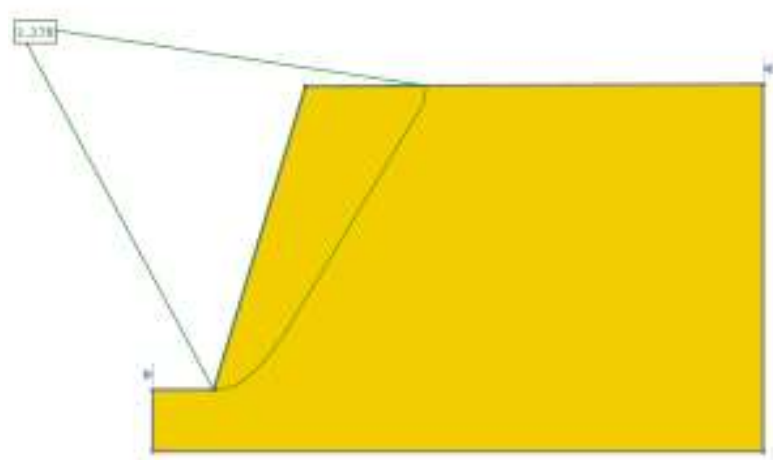

(c)

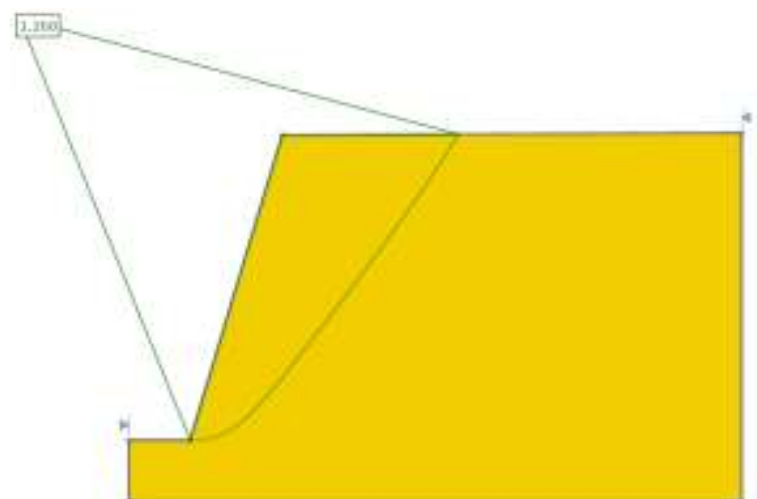

(b)

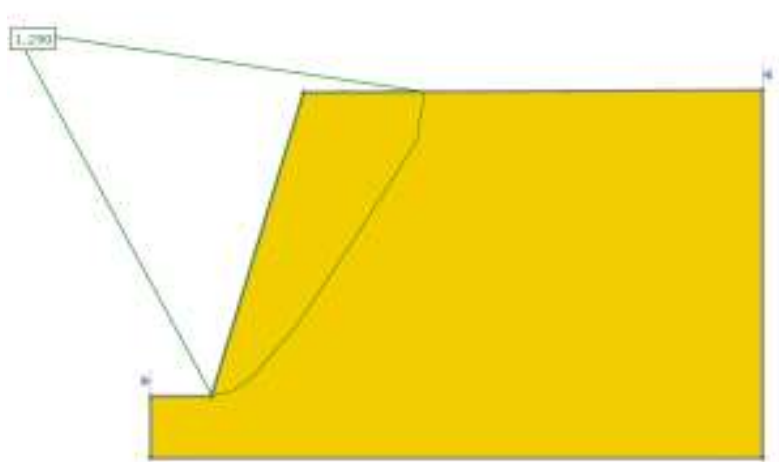

(d)

Figure 3: Results of Limit Equilibrium Stability Analysis for Siltstone using Mohr-Coulomb Criterion (a) Bishop Method; (b) Janbu Method; (c) Spencer Method; (d) Morgenstern-Price Method

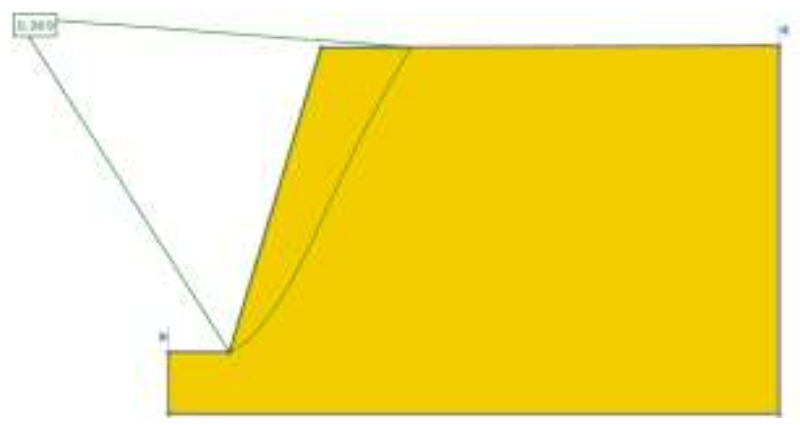

(a)

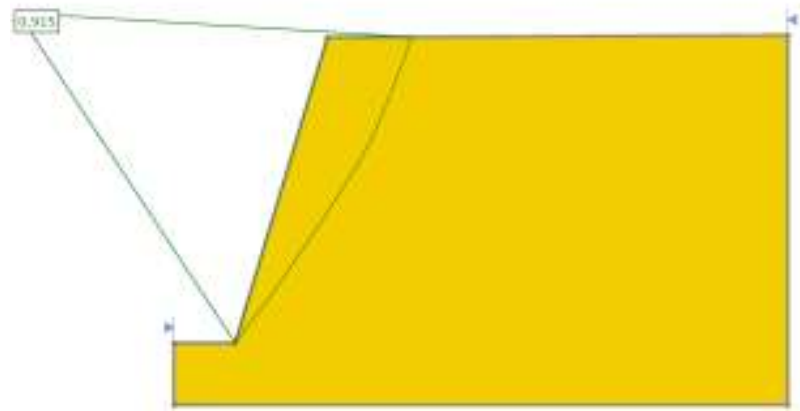

(c)

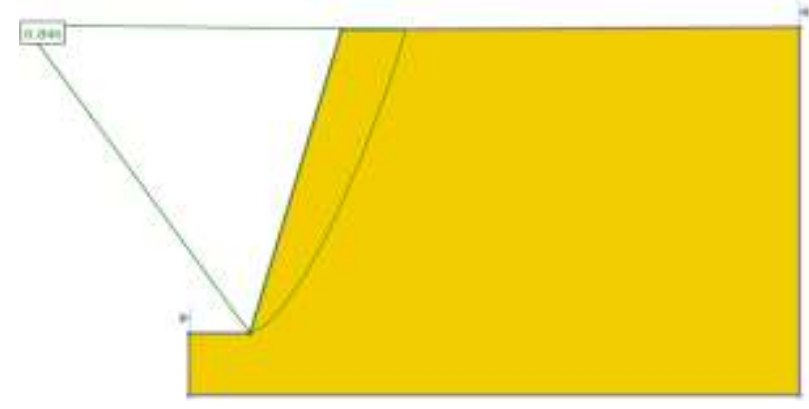

(b)

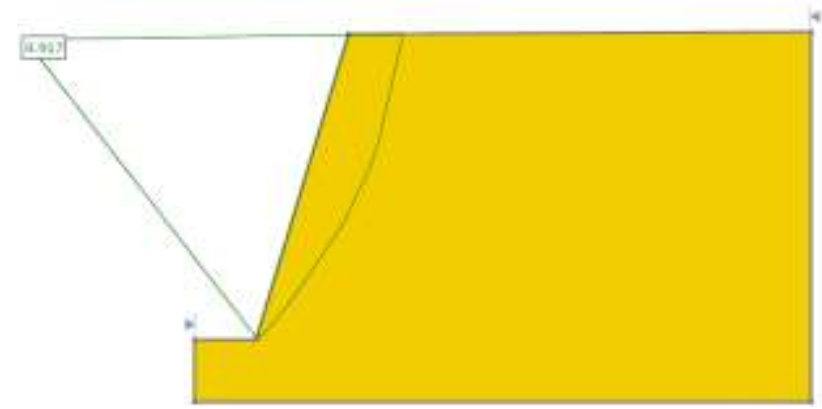

(d)

Figure 4: Results of Limit Equilibrium Stability Analysis for Siltstone using Hoek-Brown Criterion (a) Bishop Method; (b) Janbu Method; (c) Spencer Method; (d) Morgenstern-Price Method

Moreover, the areas of potential failure surface predicted by using Bishop, Janbu, Spencer and Morgenstern-Price methods when Mohr-Coulomb criterion is used are $49.76 \mathrm{~m}^{2}, 55.99 \mathrm{~m}^{2}, 54.78 \mathrm{~m}^{2}$ and 53.38 , respectively. Therefore, the minimum and maximum values of the minimum factors of safety are obtained by using Spencer and Janbu methods with Mohr-Coulomb 
criterion, respectively. Also, Bishop and Janbu methods predict the minimum and maximum values of the area of potential failure surface, respectively.

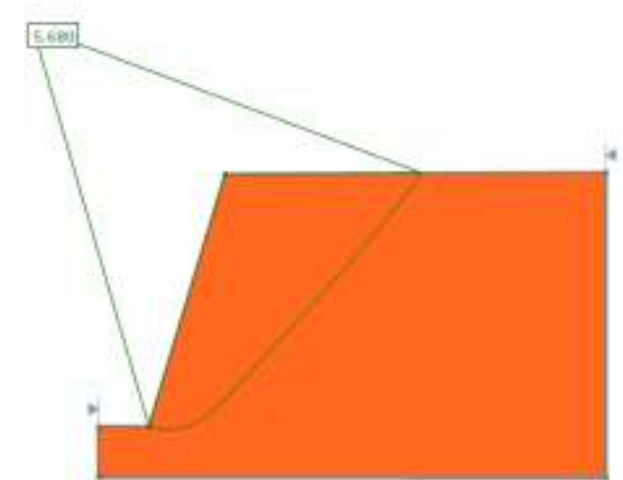

(a)

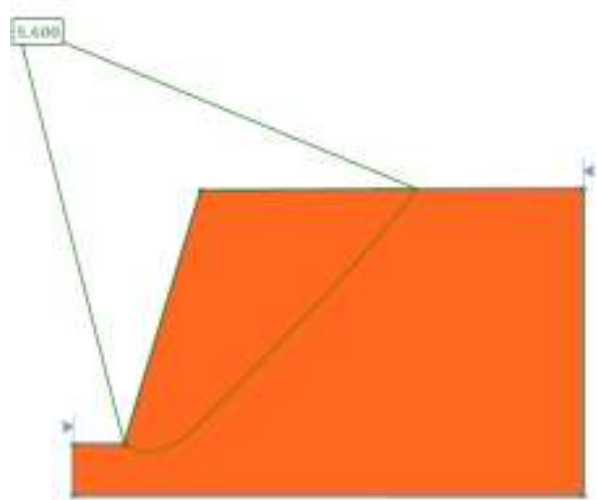

(c)

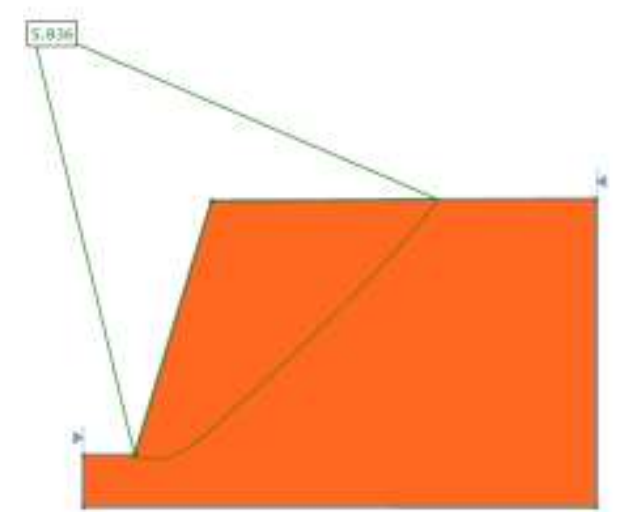

(b)

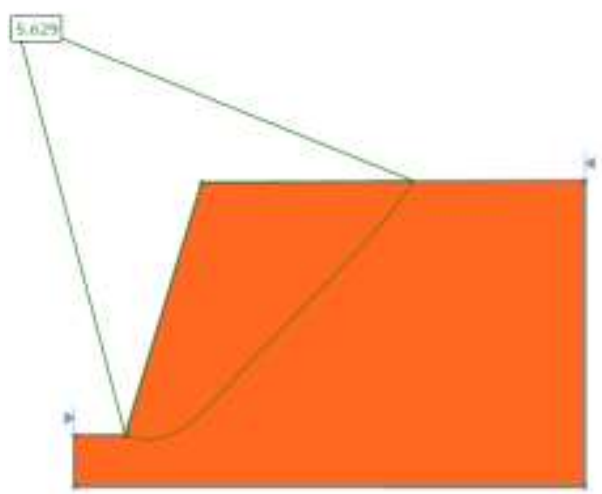

(d)

Figure 5: Results of Limit Equilibrium Stability Analysis for Limestone using Mohr-Coulomb Criterion (a) Bishop Method; (b) Janbu Method; (c) Spencer Method; (d) Morgenstern-Price Method

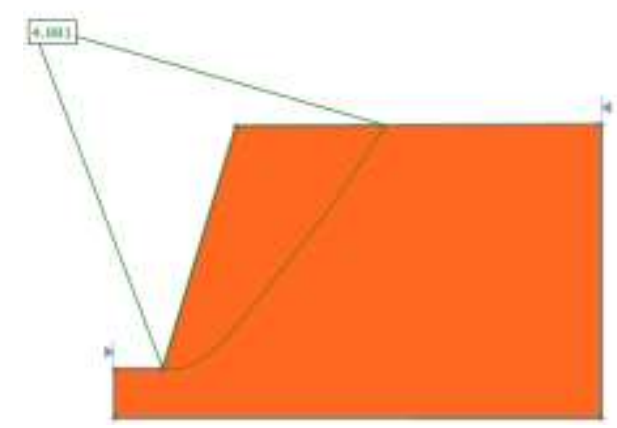

(a)

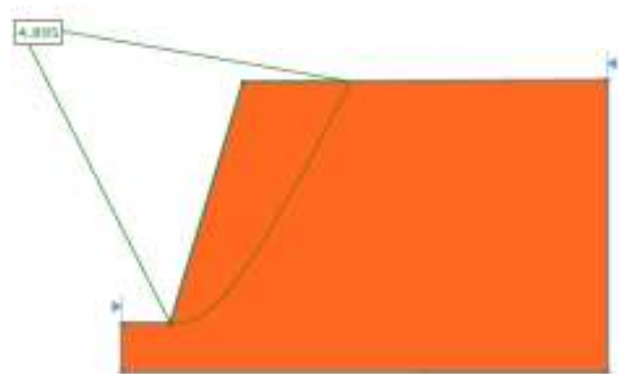

(c)

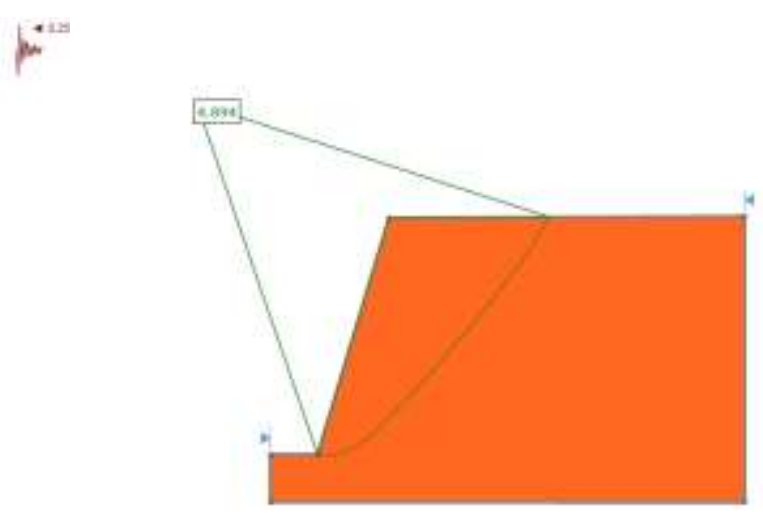

(b)

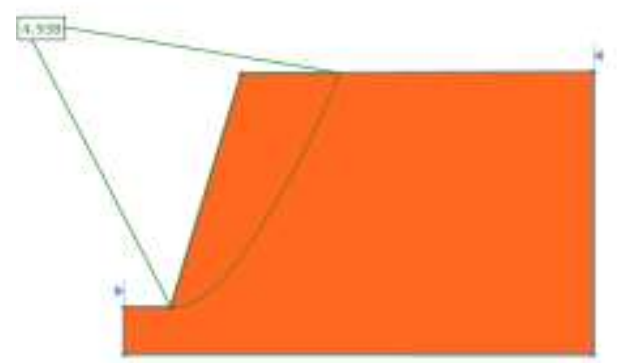

(d)

Figure 6: Results of Limit Equilibrium Stability Analysis for Limestone using Hoek-Brown Criterion (a) Bishop Method; (b) Janbu Method; (c) Spencer Method; (d) Morgenstern-Price Method 
For case 2, the calculated minimum factors of safety using Bishop, Janbu, Spencer, and Morgenstern-Price methods with Generalized Hoek-Brown Criterion are 4.881, 4.894, 4.895 and 4.938, respectively, and the predicted areas of potential failure surface are $39.59 \mathrm{~m}^{2}, 44.10 \mathrm{~m}^{2}, 30.93 \mathrm{~m}^{2}$ and $30.45 \mathrm{~m}^{2}$, respectively. As can be seen, for this case, Bishop and Morgenstern-Price methods predict the minimum and the maximum values of the minimum factor of safety, respectively. Moreover, the minimum and the maximum values of the area of potential failure surface are calculated using Morgenstern-Price and Janbu methods, respectively.

\subsection{Case 3: Sandstone}

The model configuration, potential failure surfaces, and results obtained from the modeling for the rock type of Sandstone (i.e., case 3) are presented in Figures 7 and 8 for Mohr-Coulomb and Generalized Hoek-Brown criteria, respectively.

The minimum factors of safety for this case calculated using Bishop, Janbu, Spencer, and Morgenstern-Price methods when Mohr-Coulomb criterion is used are 9.693, 10.029, 9.588 and 9.637, respectively. Also, the areas of potential failure surface predicted by using Bishop, Janbu, Spencer, and Morgenstern-Price methods are $56.32 \mathrm{~m}^{2}, 65.10 \mathrm{~m}^{2}, 66.31 \mathrm{~m}^{2}$ and $65.51 \mathrm{~m}^{2}$, respectively. The results show that, when Mohr-Coulomb criterion is used, Spencer and Janbo methods predict the minimum value and the maximum value of the minimum factor of safety, respectively. Also, Bishop and Spencer methods predict the minimum value and the maximum value of the area of potential failure surface, respectively.

For the case with Generalized Hoek-Brown criterion, using Bishop, Janbu, Spencer, and Morgenstern-Price methods, the calculated minimum factors of safety are 9.743, 10.022, 9.588 and 9.654, respectively, and the predicted areas of potential failure surface are $53.92 \mathrm{~m}^{2}, 61.19 \mathrm{~m}^{2}, 58.02 \mathrm{~m}^{2}$ and $56.62 \mathrm{~m}^{2}$, respectively. Therefore, when Generalized Hoek-Brown criterion is used, the minimum and maximum values of the minimum factors of safety are obtained by using Spencer and Janbu methods, respectively. Furthermore, Bishop and Janbu methods predict the minimum and maximum values of the area of potential failure surface, respectively.

\subsection{Case 4: Granite}

Figures 9 and 10 show the model configuration, potential failure surfaces, and minimum factors of safety obtained from the analysis using Bishop, Janbu, Spencer, and Morgenstern-Price methods for Mohr-Coulomb and Generalized Hoek-Brown criteria, respectively, when the rock type is Granite.

The minimum factors of safety for this case with Mohr-Coulomb criterion are 91.951, 96.264, 89.150 and 90.452 calculated using Bishop, Janbu, Spencer, and Morgenstern-Price methods, respectively. Moreover, the areas of potential failure surface predicted by using Bishop, Janbu, Spencer, and Morgenstern-Price methods for this case when Mohr-Coulomb criterion is used are $116.94 \mathrm{~m}^{2}, 114.77 \mathrm{~m}^{2}, 115.23 \mathrm{~m}^{2}$ and $108.47 \mathrm{~m}^{2}$, respectively. Therefore, the minimum and maximum values of the minimum factors of safety are obtained using Spencer and Janbu methods, respectively. Also, Morgenstern-Price and Bishop methods predict the minimum and maximum values of the area of potential failure surface, respectively, when Mohr-Coulomb criterion is used.

For case 4 with Generalized Hoek-Brown criterion, using Bishop, Janbu, Spencer, and Morgenstern-Price methods, the calculated minimum factors of safety are 96.278, 101.056, 93.617 and 94.798, respectively, and the predicted areas of potential failure surface are $117.32 \mathrm{~m}^{2}, 117.32 \mathrm{~m}^{2}, 111.62 \mathrm{~m}^{2}$ and $105.31 \mathrm{~m}^{2}$, respectively. As can be seen, using Hoek-Brown criterion, Spencer and Janbu methods predict the minimum and the maximum values of the minimum factor of safety, respectively. Moreover, the minimum and the maximum values of the area of potential failure surface are calculated using Morgenstern-Price methods and Bishop methods, respectively.

\section{DISCUSSION}

Tables 1 and 2 summarize the minimum factors of safety and areas of potential failure surface calculated using Bishop, Janbu, Spencer, and Morgenstern-Price methods for the four cases — Siltstone, Limestone, Sandstone and Granite — using MohrCoulomb and Generalized Hoek-Brown criteria, respectively. The calculated relative differences of safety factors and predicted areas of potential failure surface with respect to Mohr-Coulomb criterion cases are presented in Table 3 for all cases.

The results show that for weaker rock masses (i.e., Siltstone and Limestone cases), when Generalized Hoek-Brown criterion is used, all the Limit Equilibrium Methods predict lower minimum factors of safety compared to the cases with Mohr-Coulomb criterion. However, when Generalized Hoek-Brown criterion is used for rock masses with higher strength (i.e., Sandstone and Granite cases), overall higher minimum factors of safety are predicted. Moreover, as the strength of rock mass increases - from case 1 to case 4, using Generalized Hoek-Brown criterion for slope stability analysis, the relative difference of the predicted minimum factors of safety with respect to Mohr-Coulomb criterion increases. For the weakest rock mass considered in this study 
(i.e., Siltstone case), using Mohr-Coulomb predicts the slope is stable although using Hoek-Brown criterion, a landslide is predicted by all the Limit Equilibrium Methods. However, for the rock mass with the highest strength (i.e., Granite case), higher minimum factor of safety is predicted when Generalized Hoek-Brown criterion is used.

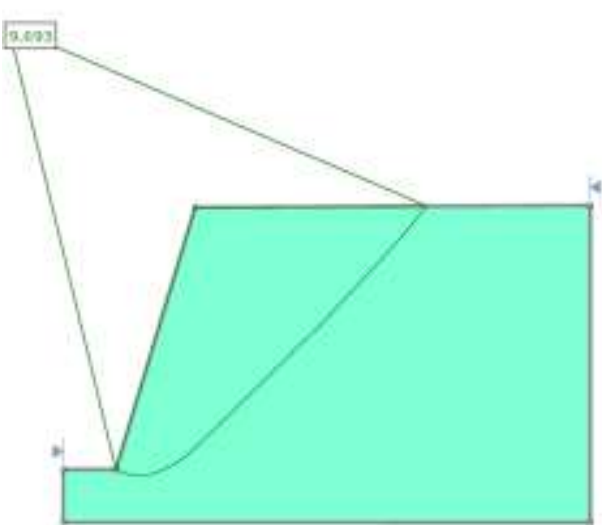

(a)

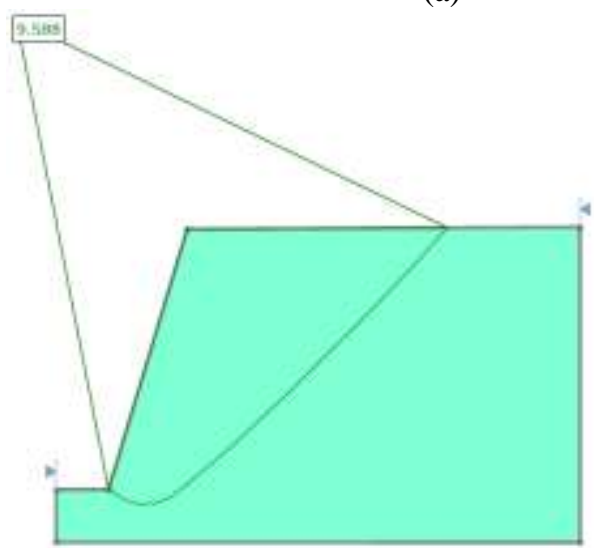

(c)

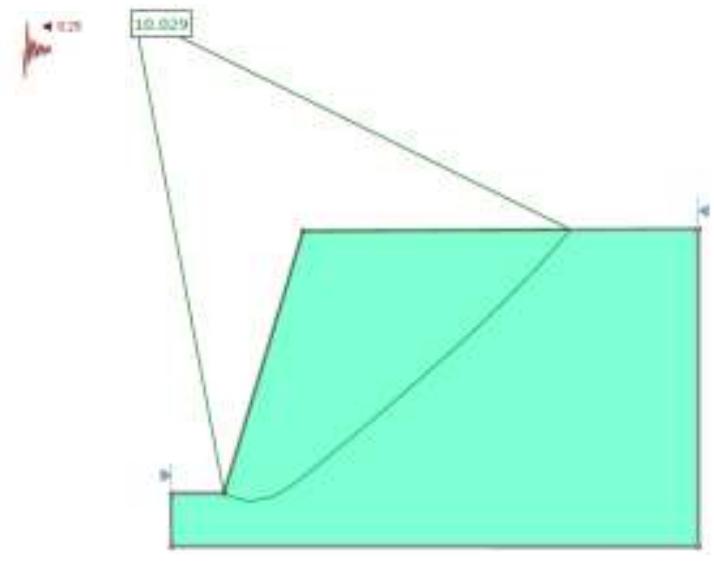

(b)

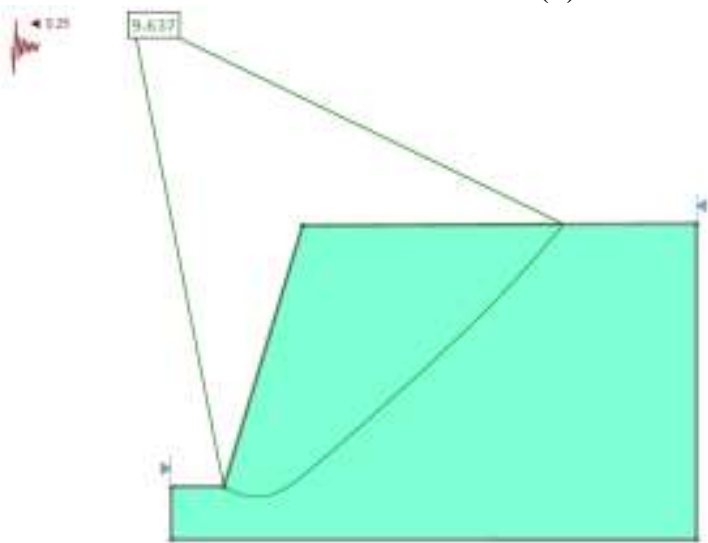

(d)

Figure 7: Results of Limit Equilibrium Stability Analysis for Sandstone using Mohr-Coulomb Criterion (a) Bishop Method; (b) Janbu Method; (c) Spencer Method; (d) Morgenstern-Price Method

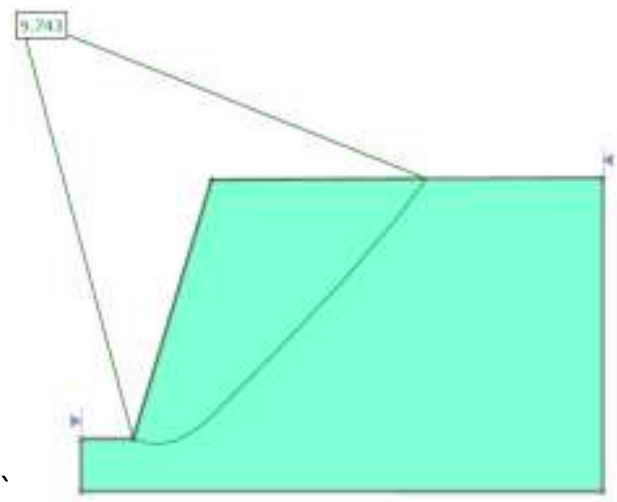

(a)

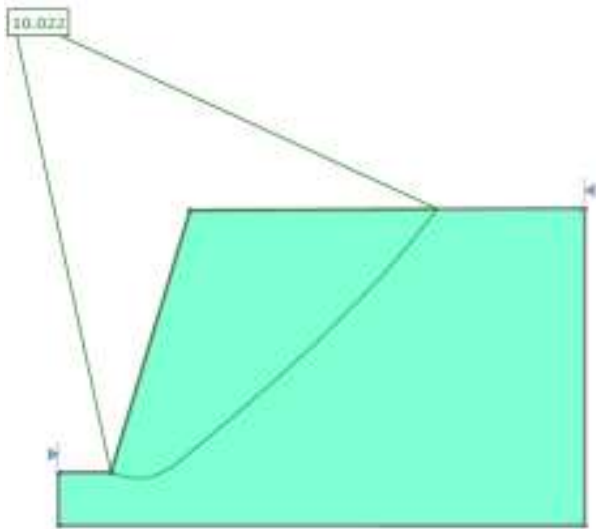

(b) 


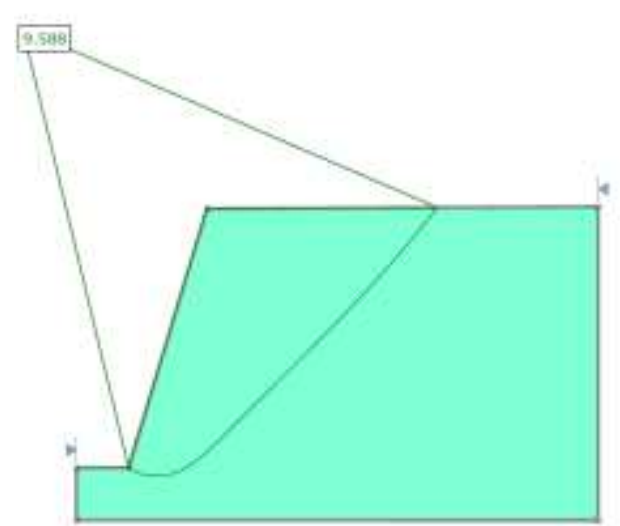

(c)

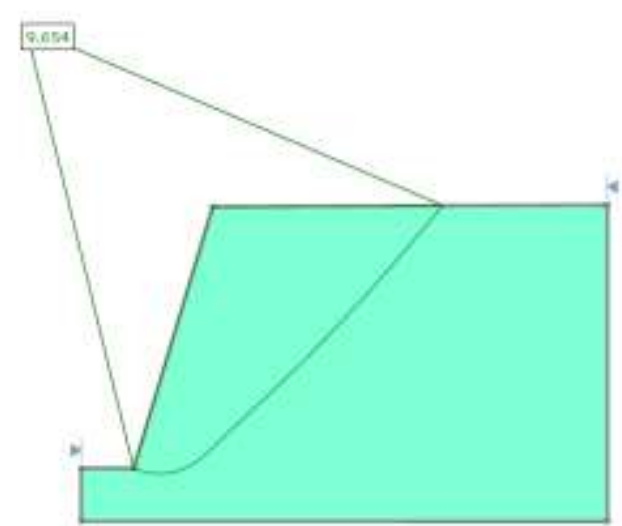

(d)

Figure 8: Results of Limit Equilibrium Stability Analysis for Sandstone using Hoek-Brown Criterion (a) Bishop Method; (b) Janbu Method; (c) Spencer Method; (d) Morgenstern-Price Method

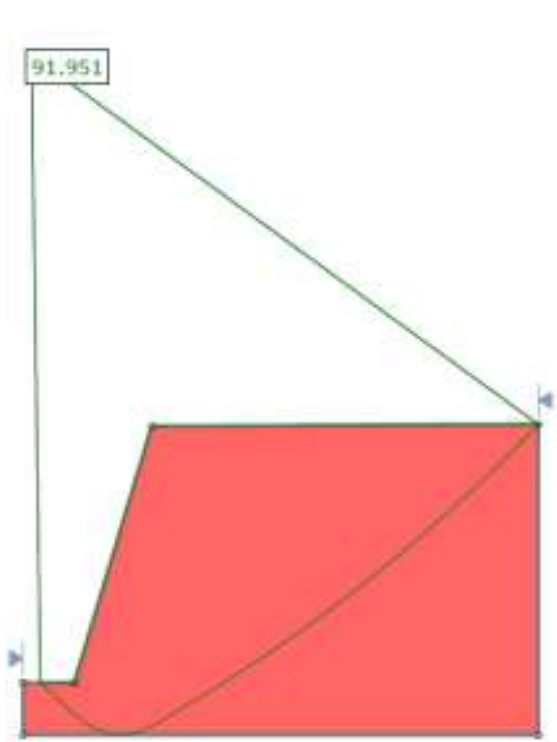

(a)

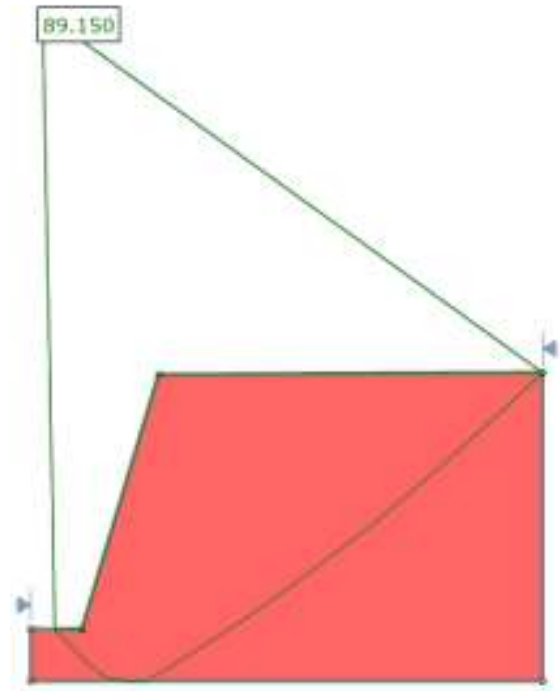

(c)

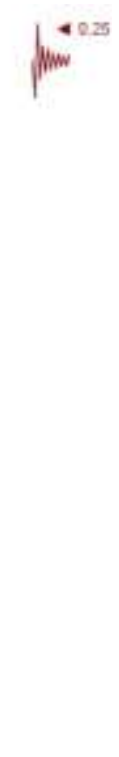

$\operatorname{limw}^{4025}$
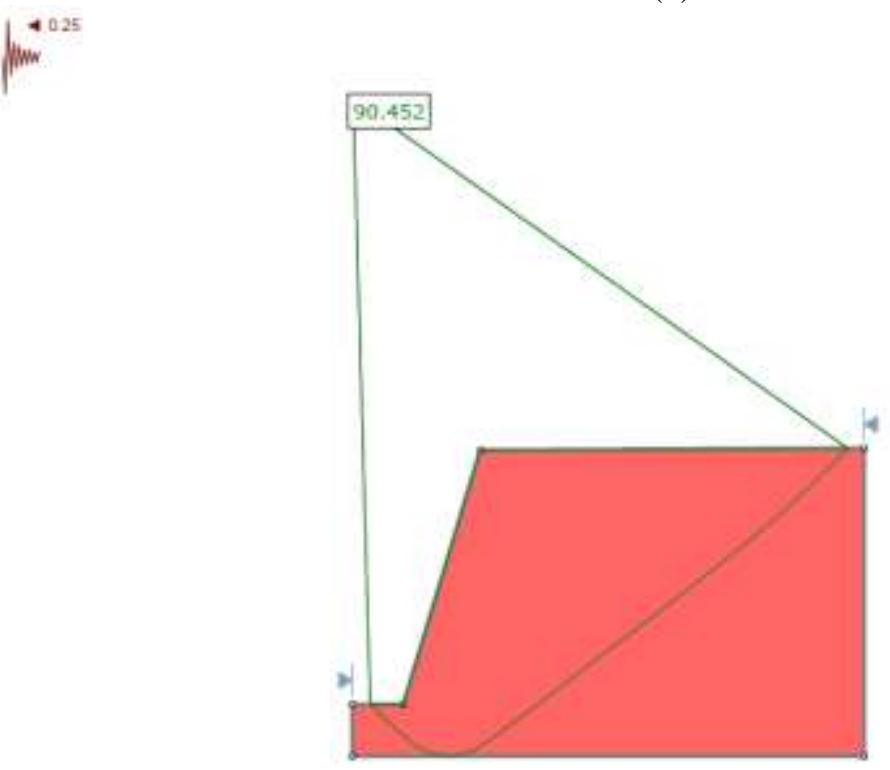

(d)

Figure 9: Results of Limit Equilibrium Stability Analysis for Granite using Mohr-Coulomb Criterion (a) Bishop Method; (b) Janbu Method; (c) Spencer Method; (d) Morgenstern-Price Method 
International Journal of Engineering Research and Advanced Technology, Vol. 7, No11, November -2021

Table 1. Results of stability analysis using Mohr-Coulomb criterion

\begin{tabular}{|c|c|c|c|c|c|c|c|c|c|}
\hline \multirow{2}{*}{ No } & \multirow{2}{*}{$\begin{array}{l}\text { Rock } \\
\text { Type }\end{array}$} & \multicolumn{4}{|c|}{ Calculated Minimum Factor of Safety } & \multicolumn{4}{|c|}{$\begin{array}{l}\text { Predicted Area of Potential Failure Surface } \\
\qquad\left(\mathrm{m}^{2}\right)\end{array}$} \\
\hline & & Bishop & Janbu & Spencer & $\begin{array}{l}\text { Morgenstern- } \\
\text { Price }\end{array}$ & Bishop & Janbu & Spencer & $\begin{array}{l}\text { Morgenstern- } \\
\text { Price }\end{array}$ \\
\hline 1 & Siltstone & 1.265 & 1.260 & 1.278 & 1.290 & 33.30 & 36.50 & 26.41 & 28.60 \\
\hline 2 & Limestone & 5.680 & 5.836 & 5.600 & 5.629 & 49.76 & 55.99 & 54.78 & 53.38 \\
\hline 3 & Sandstone & 9.693 & 10.029 & 9.588 & 9.637 & 56.32 & 65.10 & 66.31 & 65.51 \\
\hline 4 & Granite & 91.951 & 96.264 & 89.150 & 90.452 & 116.94 & 114.77 & 115.23 & 108.47 \\
\hline
\end{tabular}

Table 2. Results of stability analysis using Generalized Hoek-Brown criterion

\begin{tabular}{ccccccccccc}
\hline & & \multicolumn{3}{c}{ Calculated Minimum Factor of Safety } & \multicolumn{3}{c}{ Predicted Area of Potential Failure Surface } \\
$\left(\mathbf{m}^{2}\right)$
\end{tabular}

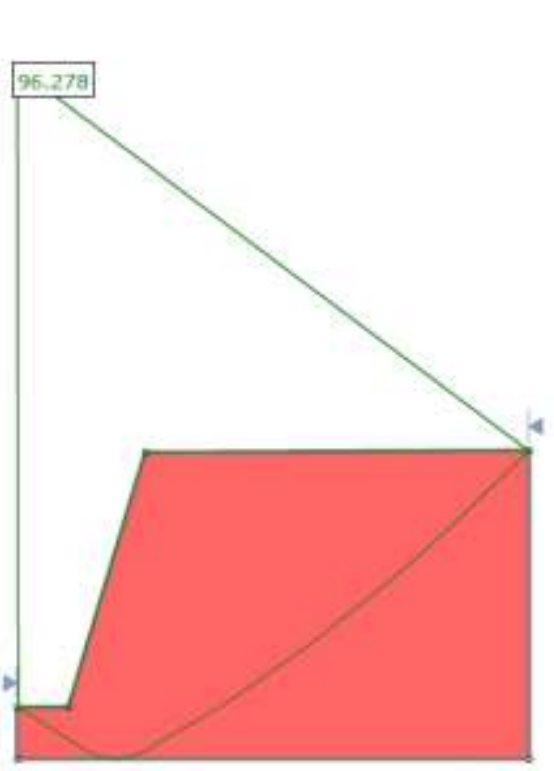

(a)

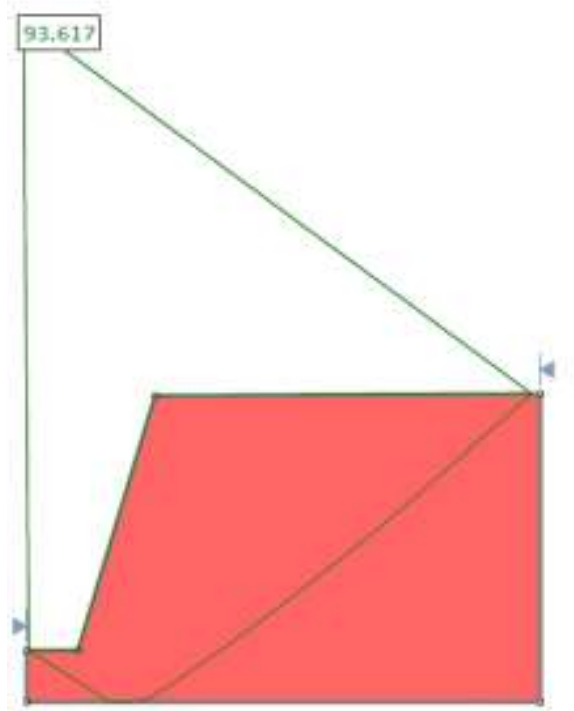

(c)

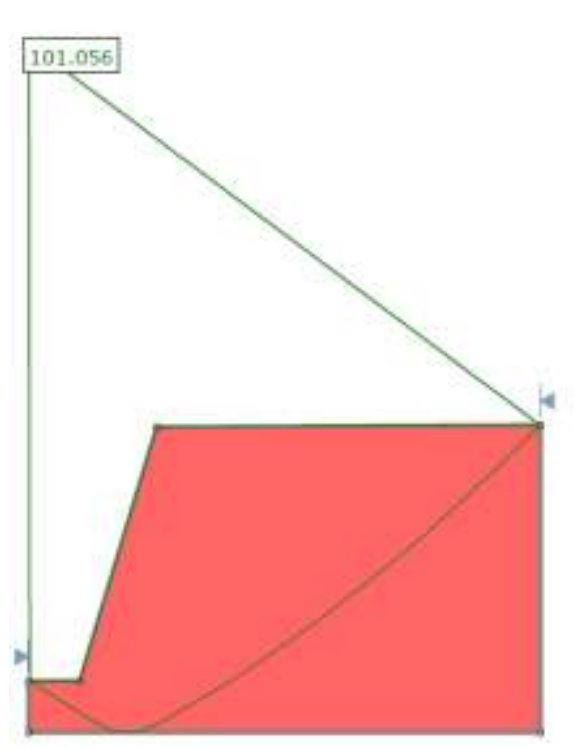

(b)

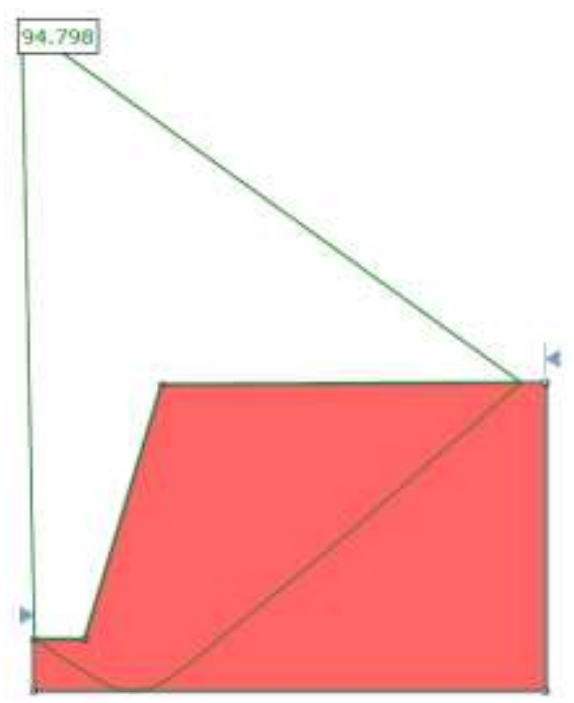

(d)

Figure 10: Results of Limit Equilibrium Stability Analysis for Granite using Hoek-Brown Criterion (a) Bishop Method; (b) Janbu Method; (c) Spencer Method; (d) Morgenstern-Price Method 
Table 3. Relative differences of safety factors and predicted areas of potential failure surface with respect to MohrCoulomb criterion cases $(\%)$

\begin{tabular}{|c|c|c|c|c|c|c|c|c|c|}
\hline \multirow{2}{*}{ No } & \multirow{2}{*}{$\begin{array}{l}\text { Rock } \\
\text { Type }\end{array}$} & \multicolumn{4}{|c|}{ Calculated Minimum Factor of Safety } & \multicolumn{4}{|c|}{$\begin{array}{l}\text { Predicted Area of Potential Failure Surface } \\
\qquad\left(\mathrm{m}^{2}\right)\end{array}$} \\
\hline & & Bishop & Janbu & Spencer & $\begin{array}{l}\text { Morgenstern- } \\
\text { Price }\end{array}$ & Bishop & Janbu & Spencer & $\begin{array}{l}\text { Morgenstern- } \\
\text { Price }\end{array}$ \\
\hline 1 & Siltstone & -23.4 & -32.9 & -28.4 & -28.9 & -46.7 & -55.7 & -33.9 & -46.6 \\
\hline 2 & Limestone & -14.1 & -16.1 & -12.6 & -12.3 & -20.5 & -21.2 & -43.5 & -42.9 \\
\hline 3 & Sandstone & 0.5 & -0.1 & 0.0 & 0.2 & -4.3 & -6.0 & -12.5 & -13.6 \\
\hline 4 & Granite & 4.7 & 5.0 & 5.0 & 4.8 & 0.3 & 2.2 & -3.1 & -2.9 \\
\hline
\end{tabular}

Similar behavior is observed for the predicted area of potential failure surface so that as the strength of rock mass increases, the relative difference of the predicted areas of potential failure surface with respect to Mohr-Coulomb criterion increases when Generalized Hoek-Brown criterion is used. As can be seen from the results, for the weakest rock mass (i.e., Siltstone), all the Limit Equilibrium methods predict higher values for the area of potential failure surface when Mohr-Coulomb criterion is used. However, higher values of the area of potential failure surface are calculated when Generalized Hoek-Brown criterion is used for the strongest rock mass considered in this study (i.e., Granite).

\section{CONCLUSIONS}

In this research, the most important Limit Equilibrium Methods as well as different rock strength criteria are used and compared to investigate the influence of rock strength criterion on Limit Equilibrium stability analysis of slopes under seismic conditions. For this study, four different rock types with different rock mass strength are considered. The results obtained by using all the mentioned Limit Equilibrium Methods show that when Generalized Hoek-Brown criterion is used for slope stability analysis, the relative difference of the predicted minimum factors of safety with respect to the cases with Mohr-Coulomb criterion increases as the strength of rock mass increases. Also, when Generalized Hoek-Brown criterion is used, lower minimum factors of safety compared to the cases with Mohr-Coulomb criterion - are predicted for weak rock masses. However, for rock masses with high strength, higher minimum factors of safety are obtained when Generalized Hoek-Brown criterion is used. The results obtained from this study show a similar behavior for predicting the area of potential failure surface so that when Generalized Hoek-Brown criterion is used, the relative difference of the calculated areas of potential failure surface with respect to Mohr-Coulomb criterion cases increases as the strength of rock mass increases. Also, using Mohr-Coulomb and Generalized Hoek-Brown criteria generally predicts higher values for the area of potential failure surface for weak rock masses and rock masses with high strength, respectively.

For the sake of caution, geotechnical, civil, and mining engineers should use the methods that predict the lowest minimum factor of safety and largest area of potential failure surface for slope stability analysis. Therefore, it is recommended that they use Mohr-Coulomb criterion to calculate the minimum factor of safety for rock masses with high strength and to obtain the area of potential failure surface for weak rock masses. Also, it is recommended that the engineers use Generalized Hoek-Brown criterion to calculate the minimum factor of safety for weak rock masses and to obtain the area of potential failure surface for rock masses with high strength.

\section{ACKNOWLEDGMENT}

The author would like to acknowledge the support provided by McMillen Jacobs Associates for this study.

\section{REFERENCES}

1. Bozzano, F., Martino, S., Montagna, A., Prestininzi, A. (2012). Back analysis of a rock landslide to infer rheological parameters. Eng. Geol. 131, 45-56.

2. Tebbens, S.F. (2020). Landslide scaling: A review. Earth And Space Science, 7(1), 1-12.

3. Gatter, R., Cavalli, M., Crema, S., Bossi, G. (2018). Modeling the dynamics of a large rock landslide in the Dolomites (eastern Italian Alps) using multi-temporal DEMs. PeerJ, 6, e5903. 
4. Antolini, F., Barla, M. (2015). Combining Finite-Discrete Numerical Modelling and Radar Interferometry for Rock Landslide Early Warning Systems. Engineering Geology for Society and Territory, 6, 705- 708.

5. Bishop A. W. (1955). The use of the slip circle in the stability analysis of earth slopes. Géotechnique, 5(1), 7-17.

6. Spencer E. (1967). A method of analysis of the stability of embankments assuming parallel inter-slice forces. Geotechnique, 17(1), 11-26.

7. Morgenstern-Price V. E. (1965). The analysis of the stability of general slip surfaces. Geotechnique, 15(1), 79-93.

8. Li A. J., Lyamin A. V., Merifield R. S. (2009). Seismic rock slope stability charts based on limit analysis methods. Computers and Geotechnics, 36(1), 135-148.

9. Zhao L. H., Li L., Yang F., Luo Q., Liu X. (2010). Upper bound analysis of slope stability with nonlinear failure criterion based on strength reduction technique. Journal of Central South University of Technology, 17(4), 836-844.

10. Yang X. G., Chi S. C. (2013). Upper bound finite element analysis of slope stability using a nonlinear failure criterion. Computers and Geotechnics, 54(10), 185-191.

11. LI L. C., Tang C. A., Zhu W. C., Liang Z. Z. (2009). Numerical analysis of slope stability based on the gravity increase method. Computers and Geotechnics, 36(7), 1246-1258.

12. Mehdipoura I., Ghazavib M., Moayed R. Z. (2013). Numerical study on stability analysis of geocell reinforced slopes by considering the bending effect. Geotextiles and Geomembranes, 37(4): 23-24.

13. Hao F. and Wang L. (2016). Application Study of FLAC in Analysis of Slope Stability. Physical and Numerical Simulation of Geotechnical Engineering, 23, 17-23.

14. Beyabanaki, S.A.R. (2020). A Comparison Between Using Finite Difference and Limit Equilibrium Methods for Landslide Analysis of Slopes Containing a Weak Layer. American Journal of Engineering Research (AJER), 9(12), 68-79.

15. Pradhan, S. P. and Siddique, T. (2020). Stability assessment of landslide-prone road cut rock slopes in Himalayan terrain: A finite element method based approach. J. Rock Mech. Geotech. Eng., 12, 59-73.

16. Beyabanaki, S.A.R., Bagtzoglou A.C., \& Liu, L. (2016). Applying disk based discontinuous deformation analysis (DDA) to simulate Donghekou landslide triggered by the Wenchuan earthquake. Geomechanics and Geoengineering, 11(3), 177-188.

17. Beyabanaki, S.A.R. (2019). Applications of Three-Dimensional Discontinuous Deformation Analysis: A Review. American Journal of Engineering Research (AJER), 8(10), 237-245.

18. Dong, M., Li, Y. \& Li Y. (2018). Analysis of development process of landslide accumulation body based on discrete element method. Earth and Environmental Science, 170, 1-9.

19. Vinay K., Burman A., Himanshu N., Gordan B. (2021). Rock Slope Stability Charts Based on Limit Equilibrium Method Incorporating Generalized Hoek-Brown Strength Criterion for Static and Seismic Conditions. Environmental Earth Sciences, 80(212), 1-20.

20. Beyabanaki, S.A.R., Bagtzoglou A.C., Anagnostou E.N. (2016). Effects of groundwater table position, soil strength properties and rainfall on instability of earthquake-triggered landslides. Environ Earth Sciences, 75, $1-13$.

21. Huang, Y.H. (2014). Slope Stability Analysis by the Limit Equilibrium Method: Fundamentals and Methods. ASCE Press, pp 1-376. ISBN: 978-0784412886.

22. Sarkar S., Pain A., Samanta M., Kanungo D.P. (2015). Hill Slope Stability Based on Generalized HoekBrown Criterion-A Case Study from Sikkim Himalaya. Int. Conf. on Engineering Geology in New Millennium, Delhi, India, October 2015, pp 1274- 1281.

23. Deng D., Zhao L., Li L. (2017). Limit equilibrium analysis for rock slope stability using basic Hoek-Brown strength criterion. J Cent South Univ, 24, 2154-2163.

24. Kumar, V., Himanshu, N. Burman, A. (2019). Rock slope analysis with nonlinear Hoek-Brown criterion incorporating equivalent Mohr-Coulomb parameters. Geotechnical and Geological Engineering, 37, 47414757. 
25. Kang, K., Fomenko, I.K., Wang, J. and Nikolskaya, O.V. (2020). Probabilistic Assessment of Rock Slope Stability in Open Pit Mine Chaarat Using the Generalized Hoek-Brown Criterion. Journal of Mining Science, 56(5), 732-740.

26. Michalowski R. L., Park D. (2020). Stability assessment of slopes in rock governed by the Hoek-Brown strength criterion. International Journal of Rock Mechanics and Mining Sciences, 127, 104217.

27. Wei, Y., Liyan, W., Xing, Z., Hanhua, T., Shu, P., Yanyu, X., Wei, W., Xiaoyun, S. Jiandong, N. (2021). A rapid stability charts analysis method for rock slopes based on Generalized Hoek-Brown criterion. All Earth, 33(1), 98-107.

28. Kang, K., Zerkal, O.V., Ponomarev, A.A. and Fomenko, I.K. (2021). Probabilistic Slope Stability Assessment Under Seismic Conditions Based on the Generalized Hoek-Brown Criterion. Soil Mechanics and Foundation Engineering, 58(3), 223-229.

29. Kumar, V., Burman, A., Himanshu, N. and Gordan, B. (2021). Rock slope stability charts based on limit equilibrium method incorporating Generalized Hoek-Brown strength criterion for static and seismic conditions. Environmental Earth Sciences, 80(6), 1-20.

30. Beyabanaki, S.A.R. (2021). LEM Stability Analysis of Landslides Induced by Earthquakes: Impact of a Weak Layer. American Journal of Engineering Research (AJER), 10(05), 257-268.

31. Deng, D.P., Li, L., Zhao, L.H. (2017). Limit equilibrium method (LEM) of slope stability and calculation of comprehensive factor of safety with double strength-reduction technique. Journal of Mountain Science, 14(11), 2311-2324.

32. Hoek, E. (1983). Strength of jointed rock masses. Geotechnique, 33(3), 187-223.

33. Rocscience Inc. (2017). RocData Version 5.0 - rock strength data analysis, Toronto, Ontario, Canada.

34. Rocscience Inc, (2020). SLIDE Version 9.008 - 2D limit equilibrium analysis of slope stability, Toronto, Canada. 